\title{
Partisipasi Aktif Masyarakat dalam Pembangunan Desa Toyareka Kecamatan Ke- mangkon Kabupaten Purbalingga Jawa Tengah
}

\author{
Lilin Apriyani, ${ }^{\mathrm{a}, 1}$ Dikdik Baehaqi Arif ${ }^{\mathrm{b}, 2}$ \\ ${ }^{a}$ SMK Darul Abror, Purbalingga \\ ${ }^{\mathrm{b}}$ Program Studi PPKn, Universitas Ahmad Dahlan, Yogyakarta \\ ${ }^{1}$ apriyanililin5@gmail.com, ${ }^{2}$ dikdikbaehaqi@ppkn.uad.ac.id \\ * korespondensi
}

\begin{abstract}
ABSTRAK
Pembangunan Desa bertujuan meningkatkan kesejahteraan masyarakat desa dan kualitas hidup manusia serta penanggulangan kemiskinan melalui pemenuhan kebutuhan dasar, pembangunan sarana dan prasarana desa, pengembangan potensi ekonomi lokal, serta pemanfaatan sumber daya alam dan lingkungan secara berkelanjutan. Pembangunan desa mensyaratkan keterlibatan masyarakat dalam tahap perencanaan, pelaksanaan, dan pengawasan. Dewasa ini partisipasi masyarakat dalam pembangunan desa belum berjalan secara maksimal. Tujuan penelitian ini adalah untuk mengetahui partisipasi aktif masyarakat dalam perencanaan, pelaksanaan, dan pengawasan pembangunan desa di Desa Toyareka Kecamatan Kemangkon Kabupaten Purbalingga Jawa Tengah. Penelitian ini merupakan penelitian kualitatif dengan perangkat desa sebagai subjek penelitian. Objek penelitian ini adalah partisipasi aktif masyarakat dalam pembangunan desa, yang meliputi tiga tahapan, yaitu partisipasi masyarakat dalam perencanaan, pelaksanaan, dan partisipasi masyarakat dalam pengawasan pembangunan desa. Pengumpulan data dilakukan melalui observasi, wawancara dan dokumentasi. Analisis data dilakukan dengan langkah-langkah reduksi data, penyajian data, dan pengambilan kesimpulan/verifikasi. Keabsahan data dilakukan melalui teknik triangulasi sumber dan triangulasi teknik. Hasil penelitian menunjukkan partisipasi masyarakat dalam perencanaan pembangunan tergambar pada aktifnya masyarakat dalam mengikuti rapat atau musyawarah rutin pada tingkat RT maupun musyawarah perencanaan pembangunan tingkat desa. Partisipasi masyarakat dalam pelaksanaan pembangunan tergambar pada kegiatan gotong royong desa. Masyarakat berpartisipasi memberikan bantuan, baik dalam bentuk uang, tenaga, maupun material. Sedangkan partisipasi masyarakat dalam pengawasan pembangunan tergambar pada saat perencanaan pembangunan, masyarakat menilai keadaan wilayah masing-masing dan memberikan usulan pada saat rapat. Pengawasan masyarakat dalam pembangunan desa juga tergambar pada proses evaluasi hasil pembangunan desa.
\end{abstract}

Kata kunci: pembangunan desa; partisipasi; masyarakat; pemerintahan desa

\section{ABSTRAK}

ini adalah penelitian kualitatif. Subjek penelitian ini adalah sekretaris Desa Toyareka, Kepala Dusun 1, tokoh masyarakat, masyarakat. Objek penelitian ini adalah partisipasi aktif masyarakat dalam pembangunan desa di Desa Toyareka, yang meliputi 3 (tiga) tahapan yaitu, partisipasi masyarakat dalam perencanaan, pelaksanaan, dan partisipasi masyarakat dalam pengawasan pembangunan desa. Metode yang digunakan untuk pengumpulan data adalah observasi, wawancara dan dokumentasi. Analisis data dilakukan dengan langkah-langkah reduksi data, penyajian data, dan pengambilan kesimpulan/verifikasi. Keabsahan data dilakukan melalui teknik triangulasi sumber dan triangulasi teknik. Hasil penelitian menunjukkan bahwa partisipasi masyarakat dalam perencanaan pembangunan tergambar pada aktifnya masyarakat dalam mengikuti rapat atau musyawarah rutin pada tingkat $R T$ maupun musyawarah perencanaan pembangunan tingkat desa. Partisipasi masyarakat dalam pelaksanaan pembangunan tergambar pada pelaksanaan gotong royong desa. Masyarakat ikut berpartisipasi memberikan bantuan baik dalam bentuk uang, tenaga, maupun material. Sedangkan partisipasi masyarakat dalam pengawasan pembangunan tergambar pada perencanaan pembangunan dibuat, masyarakat sudah dapat menilai keadaan wilayah masing-masing dan kemudian memberikan usulan pada saat rapat. Pengawasan pembangunan juga tergambar pada pelaksanaan pembangunan desa, masyarakat mengevaluasi hasil pembangunan desa.

Kata kunci: pembangunan desa, partisipasi masyarakat

Copyright (C2020 Universitas Ahmad Dahlan, All Right Reserved

\section{PENDAHULUAN}

Pembangunan nasional merupakan cerminan kehendak rakyat, bertujuan untuk menyejahterakan masyarakat. Hal tersebut sebagaimana tercantum dalam Pembukaan Undang-Undang Dasar 1945 bahwa tujuan pembangunan nasional bangsa
Indonesia adalah melindungi segenap bangsa dan seluruh tumpah darah Indonesia, memajukan kesejahteraan umum, mencerdaskan kehidupan bangsa, serta ikut melaksanakan ketertiban dunia. 
Otonomi daerah memberikan isyarat bahwa pelaksanaan pembangunan di daerah harus ditunjukkan pada penyusunan strategi yang relevan dengan potensi yang ada di dalamnya, guna meletakkan landasan yang kuat untuk pembangunan pada masa yang akan datang (Djajuli, 2018). Desa yang memiliki hak otonomi asli berdasarkan hukum adat, dapat menentukan susunan pemerintahan, mengatur dan mengurus rumah tangga, serta memiliki kekayaan dan aset (Amalia \& Syawie, 2016). Hal tersebut di atas diselenggarakan dengan mengikutsertakan masyarakat desa.

Pemerintah Desa merupakan penanggung jawab utama dalam pembangunan desa, dan masyarakat sebagai pelaku pembangunan. Pembangunan desa ditujukan guna meningkatkan kesejahteraan masyarakat desa dan kualitas hidup manusia, serta penanggulangan kemiskinan melalui pemenuhan kebutuhan dasar, pembangunan sarana dan prasarana desa, pengembangan potensi ekonomi lokal, serta pemanfaatan sumber daya alam dan lingkungan secara berkelanjutan (Pasal 78 Ayat (1) UU No. 6 Tahun 2014 tentang Desa).

Desa Toyareka adalah suatu desa yang terletak di Kecamatan Kemangkon Kabupaten Purbalingga. Hasil pengamatan awal menunjukkan bahwa pelaksanaan pembangunan desa di Desa Toyareka belum terkoordinasi secara optimal. Selanjutnya, berdasarkan Rencana Kerja Pemerintahan (RKP) Desa masa jabatan kepala desa sebelumnya dan kepala desa sekarang masih ditemukan adanya sarana dan prasarana desa yang memerlukan perhatian khusus, seperti sarana jalan umum dan jembatan desa. Karena itu, diperlukan upaya untuk membangun pemahaman dan meyakinkan masyarakat untuk berpartisipasi dalam pembangunan, melalui komunikasi antara pemerintah desa dengan masyarakat ataupun sebaliknya.

Fokus penelitian ini adalah partisipasi aktif masyarakat dalam pembangunan desa. Masalah penelitian ini adalah bagaimana partisipasi aktif masyarakat dalam perencanaan pembangunan desa, dalam pelaksanaan pembangunan desa, dan dalam pengawasan pembangunan desa di Desa Toyareka Kecamatan Kemangkon Kabupaten Purbalingga Jawa Tengah? Tujuan penelitian ini adalah untuk mengetahui partisipasi masyarakat dalam perencanaan pembangunan, dalam pelaksanaan pembangunan, dan dalam pengawasan pembangunan desa di Desa Toyareka Kecamatan Kemangkon Kabupaten Purbalingga Jawa Tengah.

\section{METODE PENELITIAN}

Penelitian ini menggunakan pendekatan kualitatif dengan metode deskriptif. Penelitian ini berorientasi pada gejala yang bersifat alami di lapangan. Penelitian mengumpulkan berbagai data dan keterangan faktual secara komprehensif tentang partisipasi aktif masyarakat dalam pembangunan desa di Desa Toyareka Kecamatan Kemangkon Kabupaten Purbalingga.

Data penelitian diperoleh dengan teknik observasi, wawancara, dan dokumentasi. Berbagai teknik pengumpulan data tersebut digunakan dalam upaya mengungkap partisipasi aktif masyarakat dalam pembangunan desa. Data-data yang diperoleh kemudian diolah dan dianalisis sesuai analisis penelitian kualitatif menggunakan tiga tahapan, yaitu reduksi data, penyajian data dan penarikan kesimpulan.

\section{HASIL DAN PEMBAHASAN}

\section{Partisipasi masyarakat dalam pembangunan desa}

Partisipasi masyarakat dalam pembangunan tergambar dalam kegiatan penyerapan aspirasi atau usulan masyarakat dan kegiatan musyawarah rencana pembangunan desa. Hal tersebut dalam rangka penerapan prinsip partisipatif pembangunan masyarakat desa yang berpedoman pada prinsip-prinsip perencanaan pembangunan partisipasi yang melibatkan masyarakat dalam pengambilan keputusan (Solichin, 2017). Pertama, kegiatan penyerapan aspirasi masyarakat dimulai dari tingkat Rukun Tetangga (RT) yang menyelenggarakan rapat tingkat RT, membahas usulanusulan pembangunan yang akan diajukan kepada pihak kelurahan. Namun karena berbagai hal, untuk jumlah usulan yang diajukan masyarakat kepada pemerintah desa masih kecil, sehingga usulan tersebut lebih banyak merupakan inisiatif dari para Ketua RT.

Kedua, kemauan masyarakat Desa Toyareka untuk terlibat dalam kegiatan musyawarah rencana pembangunan sudah ada. Hal ini tergambar dari kehadiran masyarakat yang diundang. Berdasarkan isian tingkat perkembangan desa tahun 2012, jumlah kehadiran masyarakat dalam setiap kali musyawarah tingkat dusun dan desa mencapai 75\%. Sebagian besar dari masyarakat dapat menghadiri kegiatan ini. Masyarakat yang terlibat secara langsung dalam kegiatan musyawarah rencana pembangunan juga turut memberikan masukan terhadap berbagai rumusan usulan pembangunan berdasarkan skala prioritas yang akan diajukan kepada pihak pemerintah. Selain itu juga telah tampak adanya kesadaran pribadi untuk membantu terlaksananya pembangunan. Namun, bagi yang belum mengikuti secara aktif, alasan yang dikemukakan adalah mereka tidak di undang, selain ada juga masyarakat yang pasif 
mengikuti rapat karena tidak memiliki keterampilan berbicara di depan umum.

\section{Partisipasi masyarakat dalam pelaksanaan pem- bangunan desa}

Partisipasi masyarakat dalam pelaksanaan pembangunan desa tergambar dalam bentuk bantuan sumbangan dana, bentuk bantuan tenaga, dan dalam bentuk harta benda. Partisipasi tersebut biasanya digerakkan dan dipengaruhi oleh tokohtokoh masyarakat, baik formal maupun informal (Fajri, 2017). Pertama, masyarakat memiliki kesadaran akan pentingnya pembangunan, karena tanpa adanya swadaya dari masyarakat maka pembangunan tidak akan berjalan lancar. Partisipasi masyarakat dalam bentuk sumbangan uang untuk pembangunan desa terbilang cukup banyak, karena untuk menyumbang dalam bentuk bantuan keuangan sangat mudah prosedurnya dan tidak banyak menyita waktu maupun tenaga. Hal tersebut menunjukkan bahwa bantuan keuangan sebagai partisipasi masyarakat menunjukkan kesadaran bahwa pembangunan membutuhkan dana yang cukup besar.

Kedua, partisipasi masyarakat dalam bentuk bantuan tenaga termasuk dalam kategori tinggi. Hal ini karena adanya kesadaran yang cukup tinggi dari masyarakat untuk berpartisipasi secara aktif untuk pembangunan desa. Partisipasi dalam bentuk bantuan tenaga yang sifatnya seperti gotong royong merupakan suatu tradisi yang turun-temurun bagi masyarakat Desa Toyareka. Alasan lain adalah adanya suatu kebersamaan bagi masyarakat untuk membangun desanya.

Ketiga, partisipasi dalam bentuk bantuan material terkesan rumit dan melalui proses yang lama karena berimplikasi pada laporan pertanggungjawaban penggunaan material. Dengan demikian, dapat dikemukakan bahwa partisipasi masyarakat Desa Toyareka dalam pembangunan tergolong cukup baik.

\section{Partisipasi masyarakat dalam pengawasan pem- bangunan desa}

Keterlibatan masyarakat dalam pengawasan pembangunan desa tergambar pada penilaian hasil-hasil pembangunan desa. Pengawasan pemerintah desa, termasuk di dalamnya pembangunan desa merupakan peran yang dapat dilakukan Badan Permusyawaratan Desa bersama masyarakat (Roza \& Arliman, 2007). Keterlibatan masyarakat mulai dari perencanaan maupun pelaksanaan pembangunan menunjukkan secara tidak langsung bahwa masyarakat telah terlibat dalam menilai hasil-hasil pembangunan desa dan ikut terlibat dalam mengawasi jalannya pembangunan tersebut (Mustanir, 2017).
Partisipasi masyarakat dalam pembangunan membuat masyarakat merasa dilibatkan untuk memiliki hasil pembangunan tersebut (Agustina \& Solihat, 2018). Adanya keterlibatan anggota masyarakat terhadap apa yang dihasilkan melalui evaluasi suatu pembangunan merupakan indikasi berhasilnya pembangunan tersebut dan hal ini berguna dalam penyusunan kegiatan program pembangunan berikutnya.

\section{Faktor-faktor yang mempengaruhi partisipasi masyarakat dalam pembangunan desa}

Perencanaan pembangunan desa merupakan satu kesatuan dalam sistem perencanaan pembangunan daerah dan merupakan bagian dari sistem perencanaan pembangunan nasional. Masyarakat diberi kesempatan untuk terlibat dalam proses perencanaan pembangunan melalui forum-forum musyawarah dan rapat yang di selenggarakan Desa (Weni \& Maruf, 2018). Namun demikian, tidak semua anggota masyarakat dapat berpartisipasi dalam perencanaan, pelaksanaan, dan pengawasan pembangunan desa.

Faktor-faktor yang mempengaruhi masyarakat dalam pembangunan desa meliputi faktor pendukung dan faktor penghambat. Pertama, faktor pendukung dapat dikelompokkan ke dalam faktor internal dan eksternal. Faktor internal antara lain cukup tingginya penghasilan masyarakat memungkinkan partisipasi dalam pembangunan desa semakin tinggi pula, tetapi jika penghasilan atau pendapatan tidak stabil atau tidak rutin, maka akan menghambat partisipasi masyarakat dalam pembangunan desa (Hardianti, 2017). Hal tersebut sejalan dengan lamanya masyarakat tinggal di desa tersebut, maka rasa memiliki terhadap lingkungan tergambar pada partisipasinya dalam pembangunan desa. Sementara itu, faktor eksternal meliputi kepemimpinan yang baik dari pemerintah desa dan mampu berbaur dengan karakter masyarakat yang dipimpin dalam membina dan mengarahkan masyarakat untuk berpartisipasi dalam pembangunan.

Kedua, faktor penghambat. Secara internal pengetahuan dan wawasan masyarakat yang terbatas merupakan hambatan masyarakat dalam berpartisipasi dalam pembangunan desa (Hidayat \& Hidayat, 2017). Selain itu, masyarakat pada umumnya kurang memahami peran mereka dalam pembangunan. Hal ini menyebabkan kesadaran mereka terhadap pembangunan kurang optimal karena anggapan bahwa pembangunan merupakan tugas dan tanggung jawab pemerintah. Padahal untuk mewujudkan pembangunan, peran serta masyarakat secara aktif sangat diperlukan, sebab tujuan akhir dari pembangunan adalah un- 
tuk rakyat dan partisipasi mereka sangat diperlukan untuk mewujudkannya. Selanjutnya, kurangnya ketersediaan waktu masyarakat untuk berpartisipasi merupakan kendala lain dalam masyarakat untuk berpartisipasi dalam kegiatan pembangunan.

Sementara itu, secara eksternal kurangnya sosialisasi dari lembaga-lembaga pemerintah maupun swasta kepada masyarakat ketika akan melaksanakan pembangunan desa merupakan hambatan partisipasi masyarakat dalam pembangunan desa. Kurangnya sosialisasi pembangunan fisik maupun non fisik desa juga menghambat keterlibatan masyarakat dalam pembangunan desa (Azis \& Yulianto, 2019).

\section{KESIMPULAN}

Berdasarkan hasil penelitian dan pembahasan, maka dapat disimpulkan bahwa partisipasi masyarakat dalam pembangunan desa meliputi partisipasi dalam perencanaan, pelaksanaan, dan pengawasan pembangunan.

Sebelum musyawarah rencana pembangunan (Musrenbang) desa, masyarakat telah secara rutin menggali usulan-usulan pembangunan desa melalui rapat rutin RT yang diselenggarakan satu kali setiap bulan. Partisipasi masyarakat dalam pelaksanaan pembangunan desa tergambar pada pelaksanaan pembangunan yang dilakukan secara gotong royong. Sementara itu, partisipasi masyarakat dalam pengawasan pembangunan dilakukan mulai tahap perencanaan pembangunan maupun pelaksanaan pembangunan.

\section{DAFTAR PUSTAKA}

Agustiani, Y. S., \& Solihat, Y. (2018). Partisipasi Masyarakat dalam Pembangunan Infrastruktur Desa di Desa Cihambulu Kecamatan Pabuaran Kabupaten Subang. Jurnal Politikom Indonesiana, 3(2), 187-195.

Amalia, A. D., \& Syawie, M. (2016). Pembangunan Kemandirian Desa melalui konsep pemberdayaan: Suatu Kajian dalam perspektif sosiologi. Sosio Informa, 1(2).

Azis, D., \& Yulianto, D. (2019). Upaya Pemerintah Desa untuk Meningkatkan Partisipasi Masyarakat Dalam
Pembangunan Desa (Studi di Desa Sinduadi Kecamatan Mlati Kabupaten Sleman). PARADIGMA: Jurnal Ilmu Administrasi, 6(2), 197-213.

Djadjuli, D. (2018). Peran Pemerintah Dalam Pembangunan Ekonomi Daerah. Dinamika: Jurnal Ilmiah Ilmu Administrasi Negara, 5(2), 8-21.

Fajri, A., \& Wicaksono, B. (2017). Peranan Pemimpin Informal Dalam Pembangunan Desa (Studi Di Desa Pulau Terap Kecamatan Kuok Kabupaten Kampar Tahun 2014) (Doctoral dissertation, Riau University).

Hardianti, S. (2017). Partisipasi masyarakat dalam pembangunan infrastruktur desa (program alokasi dana desa di Desa Buntongi Kecamatan Ampana Kota). Katalogis, 5(1).

Hidayat, N., \& Hidayat, W. (2017). Partisipasi Masyarakat dalam Perencanaan Pembangunan Desa Banut Kalanaman Kecamatan Katingan Hilir Kabupaten Katingan. Restorica: Jurnal Ilmiah Ilmu Administrasi Negara dan Ilmu Komunikasi, 3(2), 21-25.

Mustanir, A. (2017). Partisipasi Masyarakat Dalam Musyawarah Rencana Pembangunan Di Kelurahan Kanyuara Kecamatan Watang Sidenreng Kabupaten Sidenreng Rappang. Jurnal Politik Profetik, 5(2), 247-261.

Roza, D., \& Arliman, L. (2017). Peran Badan Permusyawaratan Desa di Dalam Pembangunan Desa dan Pengawasan Keuangan Desa. Padjadjaran Journal of Law, 4(3), 606-624.

Solichin, S. (2017). Evaluasi kebijakan UU Nomor 6 Tahun 2014 tentang Desa. Mimbar: Jurnal Penelitian Sosial Dan Politik, 6(3), 69-78.

Undang Undang Republik Indonesia Nomor 6 Tahun 2014 tentang Desa

Weni, C. C. M., \& Maruf, M. F. (2018). FaktorFaktor Yang Mempengaruhi Partisipasi Masyarakat Dalam Pelaksanaan Alokasi Dana Desa (ADD) di Desa Kradinan Kecamatan Dolopo Kabupaten Madiun. Publika, 6(8). 